\title{
ECONOMIC INTEREST GROUP ALLOCATIONS IN OPEN-SEAT SENATE ELECTIONS
}

\author{
RONALD KEITH GADDIE \\ University of Oklahoma \\ JAMES L. REGENS \\ Tulane University Medical Center
}

\begin{abstract}
Most studies of political action committees (PACs) focus on the incumbent-oriented contribution strategies of PACs, whereas contributions to open-seat candidates remain relatively unexplored. Based on the assumption that open-seat candidates have an insatiable need for campaign money, we model the allocations of PACs to open-seat senate candidates from 1980 to 1994 . The results of our analyses indicate that allocations in open-seat senate elections are more partisan than those in incumbent elections, although incumbent-like effects are evident in allocations by corporate, labor, and trade association PACs, which largely support aspirant House of Representatives members who have previously existing connections to monied interests. Unlike the bipartisan behavior exhibited by investor PACs in open house races, labor and investor interests reinforce the partisan divisions in senate contests by engaging in competitive funding of opposing candidates.
\end{abstract}

Only recently has research on congressional elections turned to examine open-seat contests. The study of open seats has focused exclusively on House of Representatives races (Gaddie 1995b; Flemming 1995; Mondak 1993), and there is only one study on the financing of open-seat candidates (Gaddie 1995a). Senate open seats have been virtually ignored in political science research. Only one study has treated open-seat senate elections as a distinct category of election, and that treatment is cursory at best (Abramowitz and Segal 1992). A component of the inattention paid to open-seat senate elec-

Authors'Note: An earlier version of this article was presented at the 1994 annual meeting of the Southwestern Political Science Association, San Antonio, TX, March 30-April 2. The authors thank Charles Bullock, Euel Elliott, J. Christopher Grant, Patricia Hurley, Jeffrey Sadow, the journal editor, and the anonymous reviewers for their comments and criticisms. Any errors or misinterpretations are those of the authors. Direct all correspondence to Ronald Keith Gaddie, Department of Political Science, University of Oklahoma, Norman, OK 73019. 
tions is the lack of research on the financing of open-seat senate candidacies. Like house members, senators are more likely to initially gain office in open seats. The dramatic increase in senate retirements in the 1990s and the corresponding increase in open-seat contests mean that incumbent influences are structuring fewer senate campaigns. Therefore, an examination of how economic interests relate to nonincumbent senate candidates is warranted.

In this brief note, we examine the allocations by economic interests to open-seat senate candidates. If we assume that economic interests are more concerned about policy outputs than about influencing the partisan outcomes of individual elections per se, then interests will pursue allocation strategies that maximize the likelihood of obtaining institutional access and influence (Regens and Gaddie 1995; Grier, Munger, and Torrent 1990). Pragmatic economic interests will contribute to the likely winners, who usually are the incumbents. The certainty associated with incumbent elections is not an issue in most open-seat contests. Given the power and visibility accrued to senators as well as the relatively few senate seats available, organized interests should offer ample support to open-seat contestants. In the absence of incumbency cues, do political action committees (PACs) pursue contribution strategies that support both parties' candidates-an extension of the bipartisan relationship between private-sector interests and incumbents - or do PACs demonstrate partisan behavior that emphasizes the classic business-labor allegiances of the respective parties?

In this study, we examine the campaign allocations of three major PAC cohorts that possess clearly defined economic interests: corporations, trade associations, and labor unions ${ }^{1}$ (Grier, Munger, and Torrent 1990; Snyder 1990). We present descriptive evidence on the variation in receipts by candidate party and category of PAC, and we specify and test multivariate models designed to identify the major influences on PAC allocations to open-seat candidates.

\section{ECONOMIC POLITICAL ACTION COMMITTEES AND OPEN SEATS}

Assessing the effect of spending on congressional election outcomes has been one of the more intriguing problems addressed by 
political scientists and economists. In the Senate, the problems of sufficient data points and inequities across constituencies have plagued prior attempts to obtain meaningful results. ${ }^{2}$ Scholars who have explored the effect of campaign spending on senate election outcomes have found that the party that is able to seize the spending advantage is assumed to benefit from the additional spending (Regens and Gaddie 1995; Abramowitz and Segal 1992; Campbell and Sumners 1990). Further analysis of senate incumbent fund-raising reveals that legislator attributes such as ideology and electoral vulnerability structure the financial contributions of monied interests across levels of analysis (Grier, Munger, and Torrent 1990; Regens, Gaddie, and Elliott 1994) and that heavy reliance on PAC support precedes heavy fundraising and spending by incumbents (Regens and Gaddie 1995).

The largest source of campaign money in senate campaigns is individuals, followed by PACs and then by the parties (Regens and Gaddie 1995; Jacobson 1989). Among PACs, the vast bulk of money is provided by committees that represent groups with primarily economic concerns-corporations, professional trade associations and health maintenance organizations, and labor unions. These groups historically have aligned themselves behind the major parties, with corporate and trade groups supporting the GOP and labor backing the Democrats. However, there is ample evidence that these partisan alignments are fluid and subject to other influences that cause interests, especially private-sector ones, to cross partisan and ideological lines when engaging in political action. Starting in 1982, corporate and trade PAC allocations shifted from a partisan, ideological strategy supporting Republican candidates to a bipartisan, bet-covering strategy that emphasized incumbents (Su, Neustadtl, and Clawson 1995; Gaddie 1996). A candidate for election would be best advantaged when philosophically similar PACs follow partisan, ideological cues while PACs more attuned to the opponent's party respond to incentives to cover bets or otherwise defect from ideological loyalty. In the House, this shift worked to the advantage of Democrats running as incumbents and also benefited Democrats in open seats (Gaddie 1995a).

Prior research indicates that the practice of contributing to candidates has followed one of two strategies: to pursue electoral goals or to gain access to lawmakers (Wright 1989; Denzau and Munger 1986). 
Benefit-seeking interests will attempt to alter government to obtain benefits, either by changing the composition of government or by influencing the incumbent government to produce selective benefits. Incumbency-influence models dominate the literature on campaign finance, and monied interests are assumed to make allocations based on strategies to influence or access legislators (Wright 1989). ${ }^{3}$ The only study that explicitly examines the funding of open seats finds several factors that influence the funding decisions of economic interests (Gaddie 1995a). Based on the results of that analysis of open house races, we expect the following:

1. Economic PACs act in their own best interest. They pursue pragmatic contribution strategies to further their economic needs, which are predicated on not facing a hostile legislature. Therefore, they will seek to create linkages with potential legislators, and in so doing they will attempt to reduce the uncertainty in their investment by seeking cues to likely winners.

2. Candidates who have higher potential election costs aggressively seek PAC money. Given the high costs of a senate campaign (the average cost of an open-seat race between 1980 and 1994 was more than $\$ 3$ million in constant 1994 dollars), open-seat senate candidates should be especially aggressive in seeking support from monied interests.

3. Parties have a sense of the value of their candidates, and economic PACs invest based on party appraisals of candidates. The investment by parties in nonincumbent candidates serves as a proxy for the value of the candidacy to the party. ${ }^{4}$ Interests will use party investment as a cue to candidate quality (Fowler and McClure 1989).

4. Private economic interests engage in trade-off contribution activity that is detrimental to Republican candidates. Research in house races indicates that, as the investment in a candidate increases, there is a corresponding falloff in support for the candidate's opponent (Gaddie 1995a). However, the falloff is far greater for Republicans than for Democrats. Regens, Gaddie, and Elliott (1994) find that incumbent senators receive less support from polluting corporations when those firms invested more heavily in their opponents, indicating that such effects could be evident in open senate races.

To ascertain significance of signals received by PACs in determining allocated support, we examine the influence of four sets of variables on economic PAC allocations in open-seat senate elections. 


\section{PARTY EFFECTS}

Research on the allocations by PACs to incumbent senators indicates that a strong partisan component exists in giving by corporate, trade, and labor PACs (Regens and Gaddie 1995; Grier, Munger, and Torrent 1990). In open seats, we expect contribution patterns to be even more partisan, with labor exclusively preferring Democrats and with corporate and trade PACs more heavily supporting Republicans. The descriptive statistics in Table 1 reinforce this assumption. Corporate and labor PACs demonstrated highly partisan allocation strategies in open-seat senate races. The ratio of Republican:Democratic receipts in open seats was approximately 4:1 from corporations, while Democrats enjoyed a 25:1 receipt advantage from labor. Average trade association contributions to candidates ran about $2: 1$ to the advantage of Republicans. Overall, economic PACs gave about $\$ 250,000$ more on average (in constant 1994 dollars) to Republicans than to Democrats. By comparison, the balance of moneys from economic PACs split slightly to the Democratic advantage in open house seats during the same time period. In the multivariate analyses, candidates are separated by party to avoid potential double counting and simultaneous causation problems in the analysis.

Party organization behavior also has been important in determining the level of economic PAC investment in candidates. Fowler and McClure (1989) ascribe a gatekeeper role to the parties, indicating that the receipt of PAC money by nonincumbents was contingent on party endorsement or support for the candidates. Gaddie (1995a) finds that party investments in open-seat house candidates are a significant predictor of economic PAC support. There is a critical difference in the rules governing party investment in senate candidates versus support for house candidates. Under the Federal Election Campaign Act amendments, the parties are constrained in their giving to candidates by contribution ceilings. These ceilings for party support are a constant for house candidates but vary by population for senate candidates. Senate spending caps are developed using a per capita spending formula, and population is the overwhelming predictor of party support to the open-seat candidates under study. ${ }^{5}$ To assess the weight of party importance ascribed to a candidacy, we measure party 
TABLE 1

PAC Contributions to Open-Seat Senate Candidates, 1980-1994

\begin{tabular}{lcrrr}
\hline \hline PAC Category & $\begin{array}{c}\text { Mean and } \\
\text { Standard Deviation }\end{array}$ & Minimum & Maximum & $\begin{array}{c}\text { Percentage Receiving } \\
\text { Contributions }\end{array}$ \\
\hline Corporate & & & & \\
$\quad$ Democrats & $126,602(133,778)$ & 0 & 561,892 & 93.1 \\
$\quad \begin{array}{l}\text { Republicans } \\
\text { Labor }\end{array}$ & $514,175(343,810)$ & 387 & $1,445,452$ & 100.0 \\
$\quad$ Democrats & $227,396(148,463)$ & 0 & 610,998 & 95.3 \\
$\quad$ Republicans & $8,711(17,768)$ & 0 & 109,819 & 60.5 \\
$\begin{array}{l}\text { Trade } \\
\text { Democrats }\end{array}$ & $106,041(79,902)$ & 0 & 285,894 & 93.1 \\
$\quad$ Republicans & $212,907(122,121)$ & 39 & 433,269 & 100.0 \\
$\begin{array}{c}\text { Total candidate } \\
\text { receipts from }\end{array}$ & & & & \\
all sources & & & & 100.0 \\
Democrats & $2,957,409(2,551,402)$ & 139,249 & $12,093,549$ & 100.0 \\
Republicans & $3,169,495(2,113,068)$ & 283,095 & $9,863,651$ & \\
\hline
\end{tabular}

SOURCE: Federal Election Commission data releases, 1980-1994 (Candidate Crosstab files). All financial data are expressed in constant 1994 dollars (43 Democrats, 43 Republicans). NOTE: Standard deviations are in parentheses. $P A C=$ political action committee.

a. From all PAC, individual, and party sources.

investment as the per capita support afforded the candidate. This measure also allows us to test independently for the effects of population.

\section{CONSTITUENCY EFFECTS}

State population size should relate to the amount of money allocated to open-seat senate candidates. Population effects are evident in incumbent senate campaign expenditures as well as in the contribution strategies of economic interests to incumbents (Squire 1991). Regens and Gaddie (1995) find that corporate PACs give more heavily to senate incumbents from larger states but find no evidence that trade association or labor union contributions were related to constituency size. It is reasonable to expect similar trends in open-seat races. To capture population effects, we include a measure of state population.

Economic PACs have demonstrated unique behavior toward southern candidates. Gaddie (1995a) finds that corporate and trade PACs 
have invested more heavily in southern Democrats, while labor PACs tend to eschew southerners in general. Gaddie (1996) also observes that corporate PACs give more heavily to southern Democratic incumbents. We expect trade and corporate PACs to give more heavily to southern Democrats and Republicans, whereas labor will give significantly less to southern Democrats. ${ }^{6}$

\section{CANDIDATE POLITICAL EXPERIENCE}

Candidate political experience should influence the level of support obtained from PACs. Candidates with previous political experience bring existing connections or relationships with monied interests and may possess greater fund-raising experience than do amateur candidates. A substantial body of research has tied political experience to senate challenger performance (Lublin 1994; Squire 1991), and experience is a significant indicator of open-seat house election outcomes (Gaddie 1995b; Bond and Fleisher 1991). Gaddie's (1995a) analysis of economic PAC allocations in open house races indicates that experience structures candidate receipts, with highly experienced candidates benefiting from the attention of economic interests. Indexes of political experience often rank order various officeholding experiences into cardinal scales and impose an incremental value on levels of experience. ${ }^{7}$ To better control for the impact of experience on fund-raising, we use a pair of dichotomous variables to indicate whether the candidate is a governor or a U.S. representative. Testing for experience effects in this manner allows us to control for the distinct public profile and extensive contacts that these candidates bring to campaigns. Representatives should be advantaged in economic PAC fund-raising because of their preexisting contacts inside the beltway as well as their ability to affect federal policy in the near term.

\section{TRADE-OFF AND ARMS-RACE EFFECTS}

As we already noted, one of the principal controversies in economic PAC behavior has been the shifting allocation patterns by what Snyder (1990) terms "investor PACs" (i.e., corporations and trade associations) away from partisan Republican allocations and toward a prag- 
matic, incumbent-oriented strategy that leaves GOP challengers woefully underfunded; this shift also is evident in corporate and trade contributions in open house seats (Gaddie 1995a, 1996; Su, Neustadtl, and Clawson 1995). A component of this shift in house elections is the creation of trade-offs in funding that are more detrimental to Republican candidate fund-raising. To determine whether similar effects are evident in senate contests, we control for the opponent's receipts from the same PACs. ${ }^{8}$

Given the issue-oriented, ideological nature of senate races (Abramowitz and Segal 1992), it is possible that "arms-race"" effects may be evident in open-seat senate campaigns; labor PACs will give to Democrats who are opposed by Republicans receiving substantial investor PAC support, and trade and corporate PACs will give more heavily to Republicans who oppose Democrats supported with substantial labor money. The presence of financial patterns that align investor PACs against labor clearly will differentiate PAC behavior in open senate races from the patterns observed in open house seats. ${ }^{10}$

\section{DEPENDENT VARIABLES AND MULTIVARIATE METHODS}

The dependent variables are the receipts by open-seat candidates from corporate, trade, and labor PACs, expressed in constant 1994 dollars. Data are obtained for the 86 candidates in 43 open senate seats that occurred between 1980 to 1994 . To test our assumptions about PAC allocations in open-seat elections, two forms of regression analysis are used to estimate the receipts by candidates: ordinary least squares regression (OLS) and Tobit analysis. Because the dependent variable is truncated at 0 on the left side of the distribution, the potential exists for bias in the OLS estimates. Tobit analysis corrects for this truncation and estimates the relationships between the independent and limited dependent variables while correcting for the left-hand censoring of the dependent variable (Maddala 1983; Tobin 1958). Of the six dependent variables analyzed, only one (Republican receipts from labor PACs) is skewed with more than $10 \%$ of cases being coded $0 .{ }^{11}$ We are confident in the validity of the OLS results for the other five analyses; we present the Tobit analyses as a check on the OLS estimates. ${ }^{12}$ 


\section{RESULTS}

The results of the analysis appear in Table $2 .{ }^{13}$ The specified equations reduce the unexplained variance by $25 \%$ to $50 \%$, and the fit of the Tobit analyses and the OLS regression estimates are consistent across models. Furthermore, the level of significance and the direction of the indicator variables are consistent between the OLS and Tobit models, with one exception: The population variable just misses significance in the OLS estimates of Democratic labor receipts but is statistically significant in the Tobit analysis. The regression analyses indicate that allocations by economic PACs are highly partisan in nature. Contributions are consistently structured by candidate experience and political variables that indicate confrontations of labor and investor PACs.

Separating the effects of political experience reveals the relative importance of congressional and executive experience in gaining PAC support. Among Democrats, governors and representatives receive significantly more support than do other candidates from corporate and trade PACs, whereas Republican governors do not receive significantly more corporate or trade support. The coefficient for governors is not significant in the labor PAC analyses for either party.

There are significant trade-off and arms-race effects in open-seat senate races. Trade-off effects are apparent in contributions to Republican candidates by corporate and trade PACs. The OLS estimates indicate that these reductions are substantial—a loss of almost 70 cents in corporate money to the GOP candidate per investor PAC dollar given to the Democratic candidate and a loss of 25 cents on the dollar in trade money. No significant trade-off effects are observed in Democratic receipts. The arms-race effects advanced in our model emerge in the empirical analysis. Democrats receive significantly more support from labor when the Republican opponents are heavily funded by investor PACs. Corporate and trade support of GOP candidates similarly responds to increased support of Democrats. The magnitude of the corporate and trade $\mathrm{PAC}$ responses is greater than that of the labor PAC response ( $\beta=1.46$ for corporate response, $\beta=0.34$ for trade response, $\beta=0.14$ for labor response to investor PAC allocations to GOP candidates). 


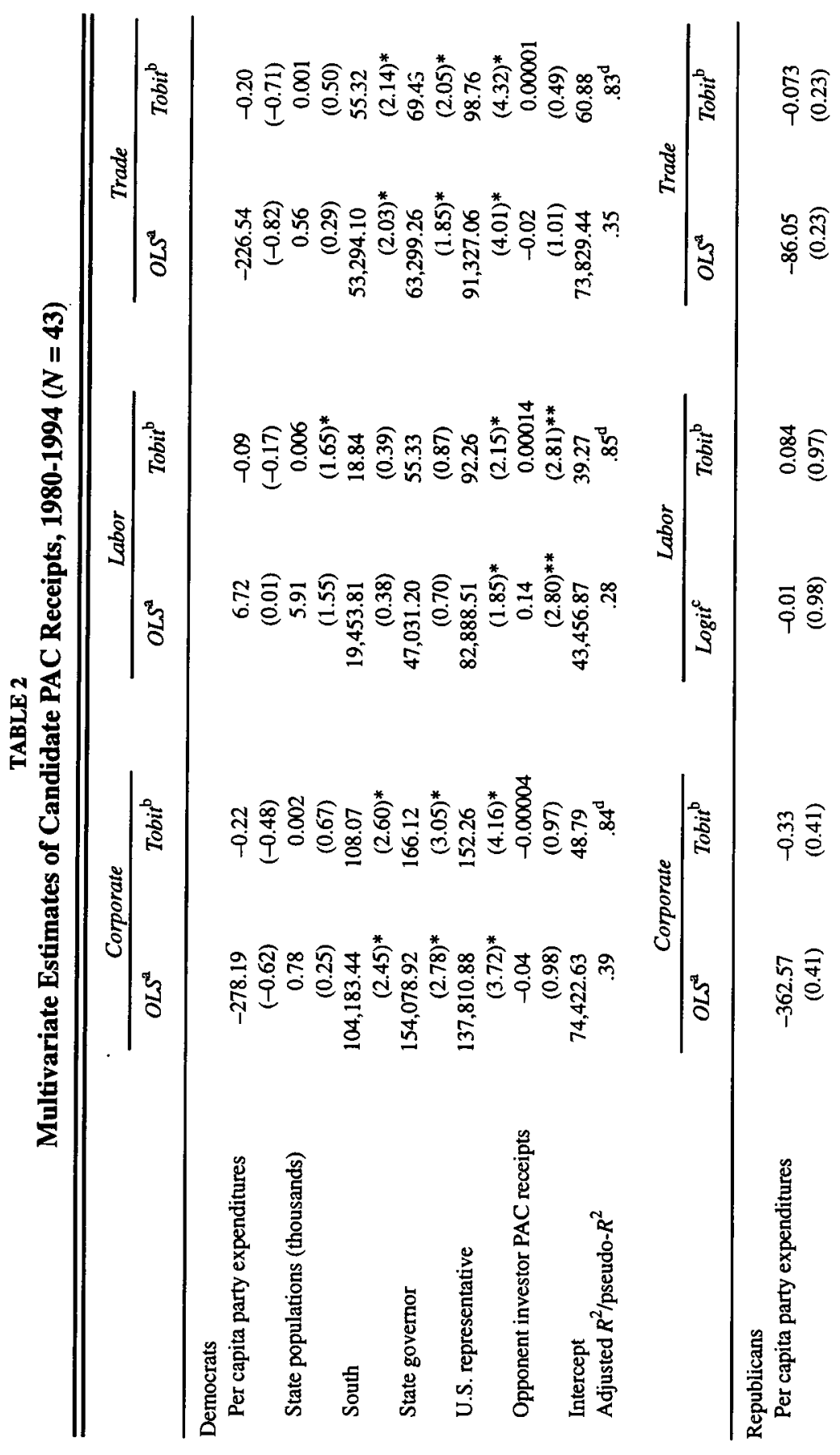




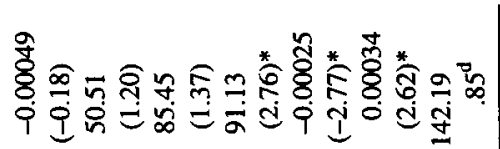

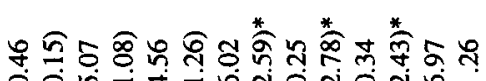

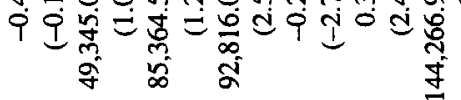

实

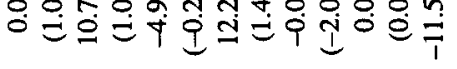

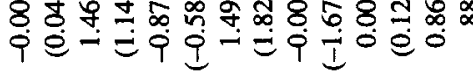

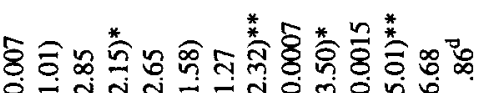

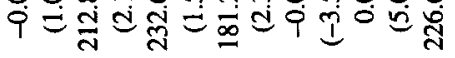

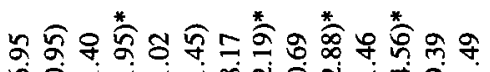

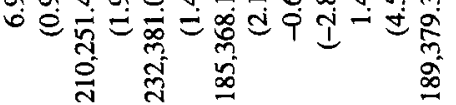

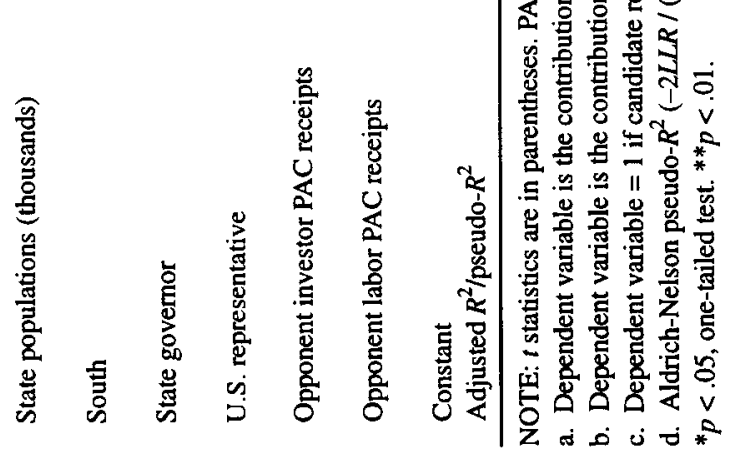


The investment by the parties is not significantly related to the receipt of money from all of the PAC cohorts examined, and significant population effects are apparent only in the receipt of labor money by Democrats. Although labor gives almost exclusively to Democrats, this result indicates that, when giving to Democrats, labor discriminates based on the need of candidates to reach more voters. Also, the greater interest of investor PACs in southern races is evident in this analysis. Southern Democrats receive significantly more money from corporate and trade PACs than do other Democratic candidates, and southern Republicans receive greater support from corporate PACs than do other GOP senate aspirants. It is interesting that the significantly lower level of labor support afforded to southern Democrats in open house seats is not observed in senate races for the same time period.

\section{CONCLUSIONS}

Unlike candidates for open house seats, senate open-seat candidates often hold highly visible, politically powerful elective positions when seeking the Senate. And, more so than in open house elections, candidates' possession of those positions structures the political action of economic interests in open senate elections. For example, as incumbents, house members are positioned to extract financial assets from organized economic interests at levels normally reserved for incumbent senators (Regens and Gaddie 1995; Parker 1992). Although it is not surprising that house incumbents exploit their institutional position, it is somewhat surprising that, in an electoral context that affords nominees high visibility, the magnitude and significance of house experience is so pronounced.

Among experienced candidates, U.S. representatives exist in an environment that encourages the development of intimate relationships that are based on political power and mutual needs of legislators and interest groups. Representatives extend those relationships to garner support while seeking higher office. Of the 86 candidates in this study, $40(46.5 \%)$ were U.S. representatives. The plurality of candidates nominated for Senate office possess prior congressional experience that enhances their ability to obtain campaign support from 
interests that normally direct their political activity exclusively toward incumbents.

When governments and voters undertake policy proposals such as term limits, they should be advised that such proposals may not result in the consequence intended by reformers. Term limits overturn incumbents and create open seats. Those candidates who are best equipped and connected to aspire to the Senate-governors and especially representatives-draw on their incumbency linkages in open seats. PACs are attracted to candidates with whom they have previously existing relationships, and these legislators and executives exploit their previously established relationships when seeking to move to higher office. However, those interest groups that provide this largesse are not craven entities that are held hostage to the financial needs of well-connected candidates. Investor PACs and labor PACs respond to the political machinations of each other in a fashion that reinforces the partisan ties of labor PACs and investor PACs to the Democratic and Republican parties, respectively. This arms-race behavior is a principal difference between house and senate elections. In open house contests, Democrats are able to benefit from the political behavior of economic interests that transcended parties and muddy the boundaries that traditionally divided corporate and labor support of candidates. In senate races, the same interests during the same time period reinforce the partisan divisions in financially competitive races.

The results of this analysis may be confined to the era under study, and the small number of cases may limit our ability to generalize from the results of the analysis. However, the robust nature of our results indicates support for our hypotheses. The use of power cues by monied interests when allocating campaign funds is indicative of a political system that emphasizes quasi-incumbent attributes. The fact that those cues structure giving in the absence of incumbents indicates that there is a limit to congressional reforms that constrains incumbents without addressing the financing of congressional elections.

\section{NOTES}

1. A fourth economic PAC cohort, cooperative PACs, is excluded from this analysis. The PACs in this small cohort are predominantly affiliated with agricultural cooperatives, and they 
have a highly focused contribution strategy that almost exclusively emphasizes the members of the agriculture committees in the House and Senate (Regens and Gaddie 1995; Grier, Munger, and Torrent 1990).

2. In the Senate, degrees of freedom problems previously have precluded the study of open seats; instead, studies of senate elections usually pool open seats with incumbent seats and then introduce various controls for incumbency (Campbell and Sumners 1990).

3. Empirical studies find that PACs respond to committee assignments of individual members, electoral vulnerability of incumbents, and ideologically extreme legislators when allocating campaign support (Grier, Munger, and Torrent 1990).

4. The parties, especially the Democrats, have limited assets to direct to their candidates and are somewhat selective in their investments.

5. Population explains virtually all of the variance in party allocations to open-seat senate candidates (adjusted $R^{2}=.99$ ).

6. For our purposes, the South is the 11 secession states; the variable is coded 1 for southem states and 0 otherwise.

7. Lublin (1994) observes that these scales often erroneously place statewide officeholding experience over congressional experience (e.g., the Squire [1991] index). Based on the use of dummy controls for different forms of experience, Lublin's 4-point index reconstitutes the rank order and ascribes the greatest experience value to house representatives, then to governors, and then to other officeholders. Initial analyses in this study suggest that although the Lublin index is useful in explaining election outcomes, it does not accurately reflect the relationship between candidate experience and candidate receipts. The cardinal scale imposed by the index does not reflect the relative valuation placed by economic interests on different candidates.

8. Initial analyses uncover similar trade-off effects by opponent trade and corporate PAC receipts on the dependent variables; therefore, we collapse both into one measure (investor PAC receipts) to save degrees of freedom. Also, GOP candidate receipts from labor PACs do not affect Democratic receipts; we likewise drop this variable in the final analysis.

9. We acknowledge James Garand's suggestion of this term.

10. There is a variety of other factors that could conceivably affect economic PAC allocations such as constituency ideology, the electoral history of the state, or year-specific shifts in funding. Controls for all of these factors have been introduced into different models in the conduct of this research, and none of the associated coefficients achieves conventional levels of statistical significance. We present the most parsimonious models of PAC giving for these races.

11. Given the skewed nature of Republican candidate receipts from labor PACs, that analysis initially is estimated using Tobit. Then we also dichotomize the dependent variable ( $1=$ receipt from labor and 0 otherwise) and estimate the model using logistic regression.

12. We examine variance inflation factors (VIF) to test for potential multicollinearity in the regression models. No VIF is greater than 2 , indicating that multicollinearity is not a serious problem.

13. The analyses also are conducted with controls for year-specific effects (Stimson 1985). Those controls are not statistically significant and do not affect the regression outcomes. Given the relatively few degrees of freedom available in the analysis, the temporal controls are eliminated to present a more parsimonious model. 


\section{REFERENCES}

Abramowitz, Alan I., and Jeffery P. Segal. 1992. Senate elections. Ann Arbor: University of Michigan Press.

Bond, Jon R., and Richard Fleisher. 1991. The experience factor in open-seat congressional elections, 1976-1988. Paper presented at the annual meeting of the Southern Political Science Association, Tampa, FL, November.

Campbell, James E., and Joe A. Sumners. 1990. Presidential coattails in senate elections. American Political Science Review 84:513-24.

Denzau, Arthur T., and Michael C. Munger. 1986. Legislators and interest groups: How unorganized interests get represented. American Political Science Review 80:89-106.

Flemming, Gregory N. 1995. Presidential coattails in open-seat elections. Legislative Studies Quarterly 20:197-211.

Fowler, Linda L., and Robert D. McClure. 1989. Political ambition. New Haven, CT: Yale University Press.

Gaddie, Ronald Keith. 1995a. Investing in the future: Economic political action committee contributions to open-seat house candidates. American Politics Quarterly 23:339-54.

- $1995 \mathrm{~b}$. Is there an inherent Democratic party advantage in U.S. house elections: Evidence from the open seats. Social Science Quarterly 76:203-12.

1996. Pragmatism and the corporate shift in political action: An alternative perspective. Social Science Quarterly 77:924-28.

Grier, Kevin B., Michael C. Munger, and Gary M. Torrent. 1990. Allocation patterns of PAC monies: The U.S. Senate. Public Choice 67:111-28.

Hagle, Timothy M., and Glenn E. Mitchell II. 1992. Goodness-of-fit measures for probit and logit. American Journal of Political Science 36:762-84.

Jacobson, Gary C. 1989. Parties and PACs in congressional elections. In Congress reconsidered, 4th ed., edited by Laurence C. Dodd and Bruce I. Oppenheimer. Washington, DC: Congressional Quarterly Press.

Lublin, David I. 1994. Quality, not quantity: Strategic politicians in U.S. senate elections, 1952-1990. Journal of Politics 56:228-41.

Maddala, G. S. 1983. Limited dependent and qualitative variables in econometrics. New York: Cambridge University Press.

Mondak, Jeffery J. 1993. Presidential coattails and open seats. American Politics Quarterly 21:307-19.

Parker, Glenn R. 1992. The distribution of honoraria income in the U.S. Congress: Who gets rents in legislatures and why? Public Choice 73:167-81.

Regens, James L., and Ronald Keith Gaddie. 1995. The economic realities of political reform: Elections and the U.S. Senate. New York: Cambridge University Press.

Regens, James L., Ronald Keith Gaddie, and Euel Elliott. 1994. Corporate PAC contributions and rent provision in senate elections. Social Science Quarterly 75:152-65.

Snyder, J. 1990. Campaign contributions as investments: The U.S. House of Representatives, 1980-86. Journal of Political Economy 98:1195-227.

Squire, Peverill. 1991. Preemptive fund-raising and challenger profile in senate elections. Journal of Politics 53:1150-64.

Stimson, James A. 1985. Regression in space and time: A statistical essay. American Journal of Political Science 29:914-47. 
Su, Tie-ting, Alan Neustadtl, and Dan Clawson. 1995. Business and the conservative shift: Corporate PAC contributions, 1976-1986. Social Science Quarterly 76:20-40.

Tobin, James. 1958. Estimation of relationships for limited dependent variables. Econometrica 26:24-36.

Wright, John R. 1989. PAC contributions, lobbying, and representation. Journal of Politics 51:713-29.

Ronald Keith Gaddie is an assistant professor of political science at the University of Oklahoma. His research has appeared in American Politics Quarterly, Political Research Quarterly, Social Science Quarterly, and the Journal of Conflict Resolution. His most recent book (edited with John C. Kuzenski and Charles S. Bullock III) is David Duke and the Politics of Race in the South (Vanderbilt University Press). His research interests include interest groups, elections, and southern politics.

James L. Regens is Freeport-McMoRan professor of environmental policy and director of the Energy Spatial Analysis Research Laboratory at Tulane University Medical Center. He is the coauthor (with Robert W. Rycroft) of The Acid Rain Controversy and the coauthor (with Ronald Keith Gaddie) of The Economic Realities of Political Reform: Elections and the U.S. Senate. His principal research interests are in risk perception, geospatial environmental modeling, and policy analysis. 